\title{
Evaluation of Dietary Medicinal Plants and algae in Laying Japanese Quails
}

\author{
Hassan Habibi ${ }^{1}$, Najmeh Ghahtan ${ }^{2}$ and Mohammad Amin Kohanmoo ${ }^{1}$ \\ ${ }^{1}$ Assistant Professor of Agricultural and Natural Resources College, Persian Gulf University, Bushehr, Iran \\ ${ }^{2}$ Student of Horticultural Sciences, Agriculture and Natural Resources College, Persian Gulf University, Bushehr, Iran \\ *Corresponding author's Email: h.habibi@pgu.ac.ir ; ORCID: 0000-0001-8162-6205
}

Received: 01 May 2019

Accepted: 28 May 2019

\begin{abstract}
The current study was conducted to examine the influences of Sargassam cristafolium, Gracilaria pulvinata, Rhus coriaria, and Punica granatum peel dried powder in two levels $(10$ and $20 \mathrm{gr} / \mathrm{kg})$ of dietary on productive performance and some egg quality characteristics of laying Japanese quail. A total of 675 (49 days old) Japanese quail were randomly distributed into nine groups with three replicates of 25 birds in each. Results showed that egg weight, shell weight, albumen weight and shell thickness were not influenced by treatments. The effects of medicinal plants on weekly egg production differ depending on the dietary medicinal plant type and dosage. Moreover, the birds fed diet supplemented with Sargassum cristaefolium at $10 \mathrm{~g} / \mathrm{kg}$ had greater weekly egg production compared to others. Haugh unit was reduced by diet supplemented with $R$. coriaria. Diet supplemented with S. cristaefolium at 20 $\mathrm{g} / \mathrm{kg}$ increased yolk weight. Furthermore, greater albumen protein and thiobarbituric acid content of the tenth day's eggs $\left(\operatorname{TBAd}_{10}\right)$ were perceived in birds fed diet supplemented with G. pulvinata. In present study, the lowest levels of cholesterol $(9.66 \mathrm{mg} / \mathrm{g})$ was determined in the egg yolk of groups $R$. coriaria and G. pulvinata, and the control group showed to have the most amounts $(12.00 \mathrm{mg} / \mathrm{g})$. Based on obtained data, addition of $0.5 \%$ and $2 \%$ of $S$. cristafolium, G. pulvinata, $R$. coriaria, and $P$. granatum peel to the diet lead to be progress in egg production rate, enhanced the egg quality and egg biochemical properties in Japanese quail.
\end{abstract}

Key words: Egg production, Egg quality, Laying quails, Medicinal plants, Thiobarbituric acid

\section{INTRODUCTION}

Protein with animal source such as eggs are of a major significance for balanced and adequate human nutrition and health (Al-Daraji et al., 2010). Recently, antibiotics have been used as growth promoters for higher yields in poultry production (Sinar et al., 2013; Mehdi et al., 2018). However, the use of antibiotics in animal nutrition has a negative consequence because animals will become resistant to antibiotics and residues of antibiotics in animal products will be carried away over eggs and meat (Abd ElGalil and Henda, 2015). Thus, search for effective alternatives to antibiotics in intensive animal production is a very important topic, considering not only the impact in animal welfare but also in human health (Abd El-Galil and Henda, 2015). The use of herbs and algae as poultry feed ingredients is continuously increasing after the ban of nutritive antibiotics in the European union (Gerzilov et al., 2015; Abouelezz, 2017). During the last ten years, the beneficial nutritional aspects and pharmaceutical of seaweeds have been advertised extensively worldwide, and therefore the algae enterprises started to gain a clear interest among producers (De Almeida et al., 2011; Abouelezz, 2017). There is a wide variety of active compounds such as carotenoids, vitamin $\mathrm{B}_{12}$, vitamin $\mathrm{C}$, thiamin, riboflavin, pyridoxine in algae, and it could be applied in the diets of layers and chicken, to improve the quality of yolk and flesh (Abouelezz, 2017; Aljumaily and Taha, 2019). Fucosan or sulfated fucans is a polysaccharide mainly produced by brown algae. Fucoidan has been reported with high and various bioactivities such as immunostimulating activity, anticancer, antiinflammatory, antiviral, anticoagulant, anti-thrombosis, anti-liver fibrosis and antioxidant (Isnansetyo et al., 2016).

Herbal products are harmless to humans and animals with no undesired side effects. In addition, there is no complication of drug resistance due to their consumption (Behnamifar et al., 2015). Aminzade et al. (2012) 
recommended the use of dietary antioxidants to reduce lipid peroxidation in the feeding animal and to preserve product quality. Punica granatum and $R$. coriaria are medicinal plants with antioxidant properties (Sharbati et al., 2015; Yassein et al., 2015). In one study, it was found that diet supplemented with $15 \mathrm{~g}$ PPP/kg (pomegranate peel powder) led to improve in production, physiological parameters as well as meat shelf-life in Japanese quails (Yassein et al., 2015). Also, seed pulp of pomegranate ( $<15 \%$ in poultry diet) improved egg production, however, higher amounts showed detrimental effects on laying performance (Saki et al., 2014a). In another study, $R$. coriaria $\mathrm{L}$. and pomegranate peel were reported to contain high levels of tannins, flavonoids, and phenolics with antioxidant properties and improvement digestion and metabolism (Abbas et al., 2017; Gurbuz and Salih, 2017).

The present experiment was designed to study the possibility of using S. cristafolium, G. pulvinata, $P$. granatum and $R$. coriaria dried powder as supplements to Japanese quail diets to evaluate its effect on productive performance, egg quality and egg biochemical compounds.

\section{MATERIALS AND METHODS}

\section{Preparation of herbal materials}

The plants Sargassam cristafolium, Gracilaria pulvinata, Punica granatum and Rhus coriaria were harvested from their natural habitat in Bushehr province, south-west of Iran, and then were dried in a dry and dark environment. Then, obtained dried seeds were powdered.

\section{Experimental birds}

All procedures used during this study were approved by animal care committee of Persian Gulf University, Bushehr, Iran. At the beginning of the experiment, 1200 day-old quail were grown simultaneously and with the same diet until 49 days old. Then among them a total of 675 (49 days old) Japanese quail were randomly distributed into nine groups with three replicates of 25 birds each. The birds' average body weight $(212.00 \pm 4.00)$ did not differ between the experimental groups when placed in the cages at the beginning of trial period. All birds were allowed to adapt for a period of seven days, consuming a commercial laying quail's diet ad libitum (Table 1). The same diet was fed to the control group during the experimental period. Control group (C) was fed a commercial laying diet. The control group was fed with a diet containing no supplements, while other groups received diets containing $10 \mathrm{gr} / \mathrm{kg}$ or $20 \mathrm{gr} / \mathrm{kg}$ of $S$. cristafolium, G. pulvinata dried powder, $R$. coriaria dried powder and $P$. granatum peel dried powder. Under commercial conditions, the birds were offered feed and water ad libitum during a period of 28 days.

Table 1. Composition of basal diet

\begin{tabular}{lc}
\hline Ingredient & g/kg \\
\hline Corn & 518.00 \\
Soybean meal & 355.00 \\
Soybean oil & 31.40 \\
Dicalcium phosphate & 7.00 \\
Limestone & 75.00 \\
Sodium chloride & 2.80 \\
Sodium bicarbonate & 1.00 \\
L-Lys-HCl & 1.30 \\
DL-Met & 3.40 \\
Vitamin and mineral premix ${ }^{1}$ & 5.00 \\
Phytase 10000 & 0.10 \\
Total & 1000.00 \\
Analysis & \\
$\quad$ Metabolizable energy, Kcal/kg & 2800.00 \\
$\quad$ Crude protein & 19.84 \\
$\quad$ Calcium & 3.10 \\
$\quad$ Available phosphorous & 0.32 \\
Sodium & 0.15 \\
Chloride & 0.23 \\
Lysine & 1.08 \\
Methionine & 0.48 \\
Methionine + Cysteine & 0.88 \\
Threonine & 0.65 \\
Tryptophan & 0.22 \\
Arginine & 1.26 \\
Isoleucine & 0.77 \\
Valine & 0.83 \\
\hline Basal diet was provided (per kg): vitamin A, 10000 IU; vitamin D3, 4500 \\
IU; vitamin E, 65 IU; vitamin K3, 3 mg; vitamin B1, 2.5 mg; vitamin B2, \\
vitamin biotin, 0.22 mg; folic acid, 1.9 mg; vitamin $\mathrm{B} 12,0.017 \mathrm{mg}$; \\
choline chloride, 1400 mg, Mn, 120 mg; Zn, 110 mg; Fe, $20 \mathrm{mg}$ Cu, 16 \\
mg; I, 1.25 mg; Se, 0.3 mg & \\
&
\end{tabular}

\section{Production performance}

Egg collection was done daily from eight weeks of age, and eggs' weight were measured by a digital balance (Olawumi and Ogunlade, 2014). The yolk was separated from the albumen and then weighed while the albumen weight was found by subtracting the weights of yolk and shell from egg weight. Haugh unit (HU) values were calculated using the following formula (Aboonajmi et al., 2010):

$$
\mathrm{HU}=100 \log \left(\mathrm{H}+7.57-1.7 \times \mathrm{W}^{0.37}\right)
$$

Where $\mathrm{H}$ is the albumen height $(\mathrm{mm})$ and $\mathrm{W}$ is the egg weight (g). 


\section{Biochemical factors}

Yolk and albumin of three eggs obtained from each replicate were separated and their chemical composition was determined according to the methods of Association of Official Agricultural Chemists (AOAC, 1990). In order to determine the egg yolk cholesterol concentration, $1 \mathrm{~g}$ of pooled yolks of each replication was added to $9 \mathrm{ml}$ of $2 \%$ $\mathrm{NaCl}$ solution. Samples were shaken for $2 \mathrm{~h}$. Then, $1 \mathrm{ml}$ of the diluted yolk was re-diluted 10 times. In this study, $10 \mu \mathrm{l}$ of this sample was mixed with $100 \mu$ of salt solution and $1 \mathrm{ml}$ of the enzymatic reagent. The same procedure was also implemented for the standard of cholesterol. As the blank sample, $10 \mu \mathrm{l}$ of deionized water was used instead of sample or standard of cholesterol. Samples were incubated in a water bath at $37^{\circ} \mathrm{C}$ for $15 \mathrm{~min}$ and then the light absorbance of $500 \mathrm{~nm}$ was measured (Behnamifar et al., 2015).

\section{Statistical analysis}

All data were subjected to ANOVA using the general linear models procedure of SAS software (SAS, 2004). Treatment means were tested using the Duncan's (1995) multiple range test, and statistical differences declared at $\mathrm{P}<0.05$ (Duncan, 1955).

\section{Ethical approval}

The present study was approved by the Ethics Committee of the Agriculture College of Persian Gulf University. The experiments were performed in the poultry research ward, Agricultural and Natural Resources College Persian Gulf University, Boushehr, Iran.

\section{RESULTS AND DISCUSSION}

\section{Egg production and egg quality traits}

Herbal plant powder could encourage the digestive system in poultry, to improve the function of digestive enzymes as well as liver efficacy and increase the pancreatic. Expansion of the metabolism of herbal plant powder, generally carbohydrates and proteins in the major nutrient would increase growth rates (Pooryousef and Hosseini, 2012). Many medicinal plants and their extracts are used widely in poultry diets because the herbs have biological activities and stimulate the digestive system (Hamodi and Al-Khilani, 2014). Results of the effects of different levels of $S$. cristafolium, G. pulvinata, $P$. granatum peel dried powder and $R$. coriaria on Egg production and egg quality traits have been reported in tables 2, 3 and 4 .

Most egg weight and week eggs production were due to the treatment with $S$. cristafolium powder content. As macro-algae contain high levels of vitamin and trace element, as well as properties of lipid mobilization, and suitable absorption rates can lead to improvement in performance (Morshedi et al., 2018). Abd El-Galil and Henda, (2015) mentioned that anti-inflammatory, restoratives, antibacterial and anti-parasitic properties of medicinal plants can enhance the productive performance in poultry.

Table 2. Effect of different dietary herbal plant food supplement ratios on egg weight and egg production of Japanese quail from 8 to 10 weeks of age.

\begin{tabular}{lccccc}
\hline \multirow{2}{*}{ Treatment } & \multirow{2}{*}{ Egg weight $(\mathrm{g})$} & \multicolumn{4}{c}{ Weekly egg production (\%) } \\
\cline { 3 - 6 } & 11.33 & Week 8 & Week 9 & Week 10 & Week 11 \\
\hline C & 11.56 & $12.33^{\mathrm{c}}$ & $24.66^{\mathrm{b}}$ & $63.33^{\mathrm{b}}$ & $72.00^{\mathrm{b}}$ \\
S-1.0 & 11.39 & $7.33^{\mathrm{ab}}$ & $29.66^{\mathrm{a}}$ & $75.33^{\mathrm{a}}$ & $85.33^{\mathrm{a}}$ \\
S-2.0 & 10.43 & $10.66^{\mathrm{a}}$ & $37.66^{\mathrm{a}}$ & $63.66^{\mathrm{b}}$ & $79.00^{\mathrm{b}}$ \\
G-1.0 & 11.10 & $10.00^{\mathrm{a}}$ & $29.66^{\mathrm{b}}$ & $61.33^{\mathrm{b}}$ & $80.33^{\mathrm{ab}}$ \\
G-2.0 & 10.96 & $1.33^{\mathrm{c}}$ & $17.00^{\mathrm{c}}$ & $64.66^{\mathrm{b}}$ & $71.33^{\mathrm{cd}}$ \\
R-1.0 & 11.12 & $2.66^{\mathrm{bc}}$ & $15.33^{\mathrm{c}}$ & $61.33^{\mathrm{b}}$ & $70.00^{\mathrm{d}}$ \\
R-2.0 & 10.56 & $0.66^{\mathrm{c}}$ & $24.33^{\mathrm{b}}$ & $61.00^{\mathrm{b}}$ & $72.66^{\mathrm{dc}}$ \\
P-1.0 & 10.95 & $2.66^{\mathrm{bc}}$ & $14.66^{\mathrm{c}}$ & $53.66^{\mathrm{c}}$ & $67.33^{\mathrm{d}}$ \\
P-2.0 & 0.86 & 0.93 & 1.73 & 1.16 & 1.18 \\
SEM & 0.47 & 0.001 & 0.001 & 0.001 & 0.001 \\
P value & & & & \\
\hline
\end{tabular}

Egg weight was calculated as the mean of whole experimental period. ${ }^{\mathrm{A}-\mathrm{d}}$ Means within a column sharing a common superscript are not different $(\mathrm{P}<0.05)$. C: control. S-1.0: Sargassum cristafolium 1.0\%. S-2.0: Sargassum cristafolium 2.0\%. G-1.0: Gracilaria corticata 1.0\%. G-2.0: Gracilaria corticata 2.0\%. R-1.0: Rhus coriaria 1.0\%. R-2.0: Rhus coriaria 2.0\%. P-1.0: Punica granatum 1.0\%. P-2.0: Punica granatum 2.0\%. S.E.M: standard error of the means. 
Table 3. Effect of different dietary herbal plant food supplement ratios on egg quality parameters of Japanese quail on 70 days of age.

\begin{tabular}{lccccc}
\hline Treatment & HU & SW & YW & AW & ST \\
\hline C & $70.33^{\mathrm{a}}$ & 1.80 & $4.13^{\mathrm{b}}$ & 6.03 & 0.17 \\
S-1.0 & $69.66^{\mathrm{a}}$ & 1.83 & $4.40^{\mathrm{ab}}$ & 6.03 & 0.17 \\
S-2.0 & $71.33^{\mathrm{a}}$ & 1.76 & $4.73^{\mathrm{a}}$ & 6.20 & 0.15 \\
G-1.0 & $71.33^{\mathrm{a}}$ & 1.63 & $4.16^{\mathrm{b}}$ & 6.06 & 0.18 \\
G-2.0 & $70.66^{\mathrm{a}}$ & 1.60 & $4.16^{\mathrm{b}}$ & 6.06 & 0.17 \\
R-1.0 & $66.00^{\mathrm{b}}$ & 1.66 & $4.40^{\mathrm{ab}}$ & 6.00 & 0.18 \\
R-2.0 & $65.33^{\mathrm{b}}$ & 1.80 & $4.60^{\mathrm{ab}}$ & 5.23 \\
P-1.0 & $70.00^{\mathrm{a}}$ & 1.70 & $4.13^{\mathrm{b}}$ & 5.96 & 0.17 \\
P-2.0 & $69.66^{\mathrm{a}}$ & 1.63 & $4.13^{\mathrm{b}}$ & 5.96 \\
SEM & 0.88 & 0.04 & 0.05 & 0.17 \\
P value & 0.00 & 0.93 & 0.03 & 0.08 \\
\hline
\end{tabular}

HU; Haugh unit, SW; Shell weight(g), YW; Yolk weight (g), AW; Albumen weight (g), ST; Shell thickness (mm), ${ }^{\text {A-d }}$ Means within a column sharing a common superscript are not different $(\mathrm{P}<0.05)$. C: control. S-1.0: Sargassum cristafolium 1.0\%. S-2.0: Sargassum cristafolium 2.0\%. G-1.0: Gracilaria corticata 1.0\%. G-2.0: Gracilaria corticata 2.0\%. R-1.0: Rhus coriaria 1.0\%. R-2.0: Rhus coriaria 2.0\%. P-1.0: Punica granatum 1.0\%. P-2.0: Punica granatum $2.0 \%$. S.E.M: standard error of the means.

Table 4. Effect of different dietary herbal plant food supplement ratios on egg biochemical factors of Japanese quail on 70 days of age.

\begin{tabular}{lccccc}
\hline Treatment & Yolk cholesterol & Albumen protein & Egg protein & TBAd $_{\mathbf{1}}$ & TBAd $_{\mathbf{1 0}}$ \\
\hline C & 12.00 & $82.66^{\mathrm{abc}}$ & 46.33 & 2.05 & $2.59^{\mathrm{a}}$ \\
S-1.0 & 10.00 & $83.66^{\mathrm{abc}}$ & 46.66 & 1.99 & $2.50^{\mathrm{a}}$ \\
S-2.0 & 11.33 & $84.33^{\mathrm{ab}}$ & 47.66 & 1.95 & $2.48^{\mathrm{ab}}$ \\
G-1.0 & 9.66 & $85.00^{\mathrm{a}}$ & 46.66 & 1.94 & $2.52^{\mathrm{a}}$ \\
G-2.0 & 11.33 & $85.00^{\mathrm{a}}$ & 48.00 & 1.95 & $2.51^{\mathrm{a}}$ \\
R-1.0 & 10.33 & $84.00^{\mathrm{ab}}$ & 46.33 & 1.96 & $2.28^{\mathrm{bc}}$ \\
R-2.0 & 9.66 & $83.33^{\mathrm{abc}}$ & 46.66 & 1.93 & $2.24^{\mathrm{c}}$ \\
P-1.0 & 10.66 & $83.66^{\mathrm{abc}}$ & 46.33 & 1.86 & $2.24^{\mathrm{c}}$ \\
P-2.0 & 11.66 & $82.00^{\mathrm{c}}$ & 45.33 & 1.87 & $2.19^{\mathrm{c}}$ \\
SEM & 0.23 & 0.23 & 0.24 & 0.01 & 0.03 \\
P value & 0.07 & 0.01 & 0.34 & 0.27 & 0.00 \\
\hline
\end{tabular}

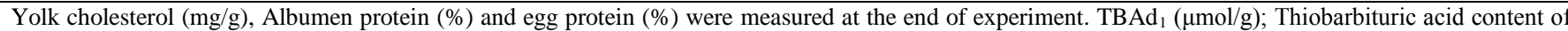
the first day's eggs, $\operatorname{TBAd}_{10}(\mu \mathrm{mol} / \mathrm{g})$; Thiobarbituric acid content of the $10^{\text {th }}$ day's eggs. ${ }^{\text {A-c }}$ Means within a column sharing a common superscript are not different (P<0.05). C: control. S-1.0: Sargassum cristafolium 1.0\%. S-2.0: Sargassum cristafolium 2.0\%. G-1.0: Gracilaria corticata 1.0\%. G-2.0: Gracilaria corticata 2.0\%. R-1.0: Rhus coriaria 1.0\%. R-2.0: Rhus coriaria 2.0\%. P-1.0: Punica granatum 1.0\%. P-2.0: Punica granatum 2.0\%. S.E.M: standard error of the means.

Therefore, they are considered as a promising dietary supplement, but data concerning their use in quail diets are limited (Abd El-Galil and Henda, 2015). Saleh et al. (2017) showed that feeding pomegranate peel diet significantly improved the daily weight gain and decreased the feed to gain ratio of broiler chickens. The effects of medicinal plants on weekly egg production differ depending on the dietary medicinal plant type and dosage. Moreover, the birds fed diet supplemented with $S$. cristafolium at $10 \mathrm{~g} / \mathrm{kg}$ had greater weekly egg production compared to others. HU was reduced by diet supplemented with $R$. coriaria (sumac). Diet supplemented with $S$. cristafolium at $20 \mathrm{~g} / \mathrm{kg}$ increased yolk weight. As noticed in table 4 , shell thickness was increased $(\mathrm{P}<0.05)$ in $G$. pulvinata and $R$. coriaria supplemented quail compared with that in those fed on control diet during $70 \mathrm{~d}$ period. In a research conducted by Saki et al. (2014a) the pomegranate seed pulp can be a potential feed supplement when added to the diets of laying hens up to $5 \%$ without negative effects on performance and egg production and quality. Higher levels will have a negative effect on egg production and quality in layers as shown by increased 
cholesterol level (Saki et al., 2014a). P. granatum and $R$. coriaria are medicinal plants with antioxidant properties (Sharbati et al., 2015; Yassein et al., 2015). It seems that an increase in yolk quality by $S$. cristafolium is due to antioxidative properties of $S$. cristafolium. This antioxidant potency can protect yolk membrane against oxidation and damages, and increase standing up quality of yolk (Jafarzadeh et al., 2014; Jahanian et al., 2017).

\section{Egg biochemical factors}

The nutritive value and functional properties of eggs make them as important animal protein source. However, consumption of eggs is often considered as a reason for some health problems due to high cholesterol content leading to coronary heart disease (Miranda et al., 2015). The medicinal plants are expected to decrease the level of cholesterol. On the other hand, herbal essential oils including fenchone, geraniol, menthone, citral, and borneol fenchyl alcohol may diminish the activity of liver HMG-CoA reductase (Behnamifar et al., 2015). Results of present study shows that dietary inclusion of G. pulvinata and $R$. coriaria decreased the concentration of egg yolk cholesterol in Japanese quail (Table 4). Medicinal active products of sumac plants are tannins, phenolic acids, anthocyanins, malic, citric and tartaric acids. Sumac's antioxidant properties are reported because of Phenolic compounds. This is probably due to the reduction of quail egg cholesterol by sumac due to the compounds present in this plant (Sharbati et al., 2015). Similar results were found by Habibi and Ghahtan (2019) who reported that the dietary addition of $20 \mathrm{~g} / \mathrm{kg} R$. coriaria powder reduced cholesterol levels on quail. Englmaierova et al. (2013) showed that supplementing layers with Algae not only increased the concentration of lutein and zeaxanthin, but also improved feed conversion ratio, shell quality, and the oxidative stability of yolk lipids of fresh and stored eggs (Englmaierová et al., 2013). Saki et al. (2014b) have shown that serum triglyceride and cholesterol did not significantly affected by supplementation of a phytogenic feed in layer diets.

The average of egg protein and albumen protein values of Japanese quail under different dietary treatments at ten week of age are presented in table 4. Egg protein (45\%) and albumen contents $(85 \%)$ are higher in $20 \mathrm{~g} / \mathrm{Kg}$ plant of G. pulvinata groups when compared to control and other experimental groups, this difference is statistically significant $(\mathrm{P} \geq 0.05)$.

Results of present study shows that supplementation of Japanese quail diet with S. cristaefolium, G. pulvinata, $P$. granatum peel and $R$. Coriaria at the rate of 10 or
$20 \mathrm{~g} / \mathrm{Kg}$ did positively influence TBA status of Japanese quail eggs (Table 4). The least TBA content of the tenth day's eggs (TBAd10) were perceived in birds fed diet supplemented with $P$. granatum peel. It seems that a decrease in thiobarbituric acid by $P$. granatum peel is due to antioxidative properties of $P$. granatum peel. Pomegranate peel extract with an abundance of flavonoids and tannins has been shown to have a high antioxidant activity (Yassein et al., 2015).

\section{CONCLUSION}

The results of this study demonstrated that using mentioned $R$. coriaria, G. pulvinata, S. cristafolium, and dried powder of $P$. granatum peel could affect egg production rate, egg quality and egg biochemical compounds of laying Japanese quails depending on the dietary medicinal plant type and dosage. Addition of 20 $\mathrm{g} / \mathrm{kg}$ S. cristafolium to the diet improved yolk weight. Furthermore, diet supplemented with G. pulvinata led to higher levels of albumen protein and thiobarbituric acid content of the tenth day's eggs $\left(\operatorname{TBAd}_{10}\right)$. Based on the findings of this study, the lowest value egg yolk cholesterol was found in the quails received G. pulvinata and $R$. coriaria while the highest amounts were detected in the control group.

\section{DECLARATIONS}

\section{Competing interests}

The authors have no competing interests to declare.

\section{Consent to publish}

All authors gave their informed consent prior to their inclusion in the study.

\section{Acknowledgements}

The authors would like to thank Ms. Afsane Esmaeili for her help with the project during experimental period. Also, we appreciate the initial improvements in English usage made by Peter Lowther through the Association of Field Ornithologists' program of editorial assistance.

\section{Author`s contributions}

Habibi and Ghahtan were involved in the data collecting, statistical analysis and drafting of the manuscript. Kohanmoo read and approved the final manuscript

\section{REFERENCES}

Abbas R.J, Al-Salhie KCK, Al-Hummod SKM (2017). The effect of using different levels of pomegranate (Punica granatum) peel powder on productive and physiological 
performance of Japanese quail (Coturnix coturnix japonica). Livestock Research for Rural Development, 29 (12): 1-7. http://www.lrrd.org/lrrd29/12/rj.a29231.html.

Abd El-Galil K and Henda AM (2015). Effect of ginger roots meal as feed additives in laying Japanese quail diets. The Journal of American Science, 11(2):164-173. DOI: 10.7537/marsjas110215.21.

Al-Daraji HJ, Razuki WM, Al-Hayanis WK and Al-Hassani AS (2010). Effect of dietary linseed on egg quality of laying quail. International Journal of Poultry Science, 9(6): 58490. DOI: $10.3923 /$ ijps.2010.584.590

Aboonajmi M, Akram A, Nishizu T, Kondo N, Setarehdan SK and Rajabipour A (2010). An ultrasound based technique for the determination of poultry egg quality. Research in Agricultural Engineering, 56(1):26-32. DOI: 10.17221/18/2009-RAE.

Abouelezz FMK (2017). Evaluation Of Spirulina Algae (Spirulina Platensis) As A Feed Supplement For Japanese Quail: Nutiritional Effects On Growth Performance, Egg Production, Egg Quality, Blood Metabolites, Sperm-Egg Penetration And Fertility. Egyptian Poultry Science Journal, 37(3):707-719. DOI: 10.21608/epsj.2017.5390

Aljumaily TKH, Taha AT (2019). Effects of Spirulina platensis Algae Extract Early Feeding on Japanese Quail Embryos. Advances in Animal and Veterinary Sciences. 7 (1); 30-37. DOI: 10.17582/journal.aavs/2019/7.1.30.37.

Aminzade B, Karami B and Lotfi E (2012). Meat quality characteristics in Japanese quails fed with Mentha piperita plant. Animal Biology and Animal Husbandry International Journal of the Bioflux Society, 4(1):20-23. Available

at:http://www.abah.bioflux.com.ro/docs/2012.20-23.pdf.

AOAC (1990). Association of Official Analytical Chemists. Off Methods Anal. 1990;15th Eddit (Washington):USA.

Behnamifar A, Rahimi S, Karimi Torshizi M, Hasanpour S and Mohammadzade Z (2015). Effect of thyme, garlic and caraway herbal extracts on blood parameters, productivity, egg quality, hatchability and intestinal bacterial population of laying Japanese quail. Iranian Journal of Veterinary Medicine, 9(3):179-87. DOI: 10.22059/IJVM.2015.55286

De Almeida CLF, Falcão HDS, Lima GRDM, Montenegro CDA, Lira NS, de Athayde-Filho PF, Rodrigues LC, de Souza MDFV, Barbosa-Filho JM and Batista LM (2011). Bioactivities from marine algae of the genus Gracilaria. International Journal of Molecular Sciences, 12(7): 45504573. DOI:org/10.3390/ijms12074550.

Duncan D (1955). Multiple range and multiple F test. Biometrics. 11:1-42. DOI: org/10.2307/3001478

Englmaierová M, Skřivan M and Bubancová IA (2013). comparison of lutein, spray-dried Chlorella, and synthetic carotenoids effects on yolk colour, oxidative stability, and reproductive performance of laying hens. Czech Journal of Animal Science, 9:412-419. DOI: org/10.17221/6941CJAS.

Gurbuz Y and Salih Y G (2017). Influence of sumac (Rhus Coriaria L.) and ginger (Zingiber officinale) on egg yolk fatty acid, cholesterol and blood parameters in laying hens. Journal of Animal Physiology and Animal Nutrition, 101 (6); 1316-1323. DOI: 10.1111/jpn.12652.

Gerzilov V, Nikolov A, Petrov P, Bozakova N, Penchev G and Bochukov A (2015). Effect of a dietary herbal mixture supplement on the growth performance, egg production and health status in chickens. Journal of Central European $\begin{array}{lll}\text { Agriculture, } & 16(2) \text { : } & 10-27 .\end{array}$ 10.5513/JCEA01/16.2.1580.

Habibi H and Ghahtan N (2019). Effects of medicinal plant powder as feed additives on growth performance, carcass characteristics, and immune response of Coturnix japonica against avian influenza and Newcastle disease vaccine virus. Comparative Clinical Pathology, (3): 1-8. DOI: https://doi.org/10.1007/s00580-019-02970-7.

Hamodi SJ and Al-Khilani FM (2014). The Effect of Supplemental Different Level of Roselle Flower in Diet on Japanese Quail Performance. Scientific Papers. Series D. Animal Science, LVII:94-8. Available at: http://animalsciencejournal.usamv.ro/pdf/2014/art14.pdf.

Isnansetyo A, Fikriyah A, Kasanah N and Murwantoko A (2016). Non-specific immune potentiating activity of fucoidan from a tropical brown algae (Phaeophyceae), Sargassum cristaefolium in tilapia (Oreochromis niloticus). Aquaculture International, 24(2): 465-477. DOI:10.1007/s10499-015-9938-z.

Jahanian E, Jahanian R, Rahmani HR and Alikhani M (2017). Dietary supplementation of Echinacea purpurea powder improved performance, serum lipid profile, and yolk oxidative stability in laying hens. Journal of Applied Animal Research, 45(1):45-51. DOI: 10.1080/09712119.2015.1091344.

Jafarzadeh A, Darmani Kuhi H, Ghavi Hossein-Zadeh N and Roostaei-Ali Mehr M (2014). Effect of dietary Aloe vera gel powder supplementation on performance, lymphoid organ weights and immune response of Japanese quails. Animal Production Research, 3(1): 31-41. https://ar.guilan.ac.ir/article_189_c0527a74e43f0c2e7c0a9 3a7fa74ea00.pdf.

Mehdi Y, Letourneau-Montminy MP, Gaucher ML, Chorfi Y, Suresh G, Rouissi Tarek, Kaur Brar S, Cote C, Ramirez AA and Godbout S (2018). Use of antibiotics in broiler production: Global impacts and alternatives. Animal Nutrition, 4:170-178. DOI: 10.1016/j.aninu.2018.03.002.

Miranda JM, Anton X, Redondo-Valbuena C, Roca-Saavedra P, Rodriguez JA, Lamas A, Franco CM and Cepeda A (2015). Egg and egg-derived foods: Effects on human health and use as functional foods. Nutrients, 7(1): 706-29. DOI: $10.3390 /$ nu7010706.

Morshedi V, Nafisi Bahabadi M, Sotoudeh E, Azodi M and Hafezieh M (2018) Nutritional evaluation of Gracilaria pulvinata as partial substitute with fish meal in practical diets of barramundi (Lates calcarifer). Journal of Applied Phycology, 30(1):619-628. DOI:https://doi.org/10.1007/ s10811-017-1199-y.

Olawumi SO and Ogunlade JT (2008). Phonotypic Correlations Between Some External and Innternal Egg Quality Traits in the Exotic Isa Brown Layer Breeders. Asian Journal of 
Poultry $\quad$ Science, $\quad 2(1)$ : $30-35$. DOI: 10.3923/ajpsaj.2008.30.35

Pooryousef Myandoab M and Hosseini Mansoub N (2012). Comparative effect of Liquorice root extract medicinal plants and probiotic in diets on performance, carcass traits and serum composition of Japanese quails. Global Veterinaria, $\quad 8(1)$ : 39-42. $\quad$ Available at:https://www.idosi.org/gv/GV8(1)12/7.pdf.

Saleh H, Golian A, Kermanshahi H and Mirakzehi MT (2017). Effects of dietary $\alpha$-tocopherol acetate, pomegranate peel, and pomegranate peel extract on phenolic content, fatty acid composition, and meat quality of broiler chickens. Journal of Applied Animal Research, 45(1):629-36. DOI: 10.1080/09712119.2016.1248841.

Saki AA, Rabet M, Zamani P and Yousefi A (2014a). The Effects of Different Levels of Pomegranate Seed Pulp with Multi-Enzyme on Performance, Egg Quality and Serum Antioxidant in Laying Hens. Iranian Journal of Applied Animal Science, 4(4): 803-808. Available at:http://ijas.iaurasht.ac.ir/article_513487.html.

Saki AA, Aliarabi H, Hosseini Siyar SA, Salari J and Hashemi M (2014b). Effect of a phytogenic feed additive on performance, ovarian morphology, serum lipid parameters and egg sensory quality in laying hen. Veterinary Research
Forum, 5 (4): 287-293. Available at:http://vrf.iranjournals.ir/article_9346_73df53c62b496ed 22cb29ca2e1af2690.pdf

Sharbati A, Daneshyar M, Aghazadeh A, Aliakbarlu J and Hamian F (2015). Effects of Rhus coriaria on nutrient composition, thiobarbituric acid reactive substances and colour of thigh meat in heat-stressed broilers. South African Journal of Animal Science, 45(1):49-55. DOI: org/10.4314/sajas.v45i1.6

Sinar TEA, Wardiny TM and Taryati D (2013). Effect of Noni Leaf Flour on Eggs Productivity of Quail. International Journal of Agriculture Food Science and Technology, 4(6):601-606.

Available at:https://www.ripublication.com/ijafst_spl/ijafstv4n6spl_1 2.pdf.

Yassein DMM, Abdallah EA, Ismail II and Faddle AA (2015). Effect Of Dietary Supplementation Of Pomegranate Peel Powder And Butylated Hydroxy Toluene On Some Productive, Physiological And Immunological Parameters Of Japanese Quail. Egyptian journal of animal production, 52:105-113.

Available 